\title{
2,4-DINITROPHENOL DOES NOT REDUCE ATP LEVELS IN STARVING HAMSTER FIBROBLASTS ALTHOUGH HEXOSE TRANSPORT REGULATION IS MARKEDLY AFFECTED
}

by

\author{
ELIEZER RAPAPORT1), PAUL PLESNER2), DONNA B. ULLREY3) \\ and \\ HERMAN M. KALCKAR 3 ) \\ 1) Department of Microbiology, Boston University School of Medicine, \\ 80 E. Concord Street, Boston, Mass. 02118, USA. \\ 2) Department of Molecular Biology, Odense University, \\ Campusvej 55, DK-5230 Odense, \\ and \\ Department of Chemistry, Carlsberg Laboratory, \\ Gamle Carlsberg Vej 10, DK-2500 Copenhagen Valby. \\ 3) Department of Chemistry, Boston University, \\ 685 Commonwealth Avenue, Boston, Mass. 2215, USA.
}

Keywords: ATP pools, 2,4-dinitrophenol, hexose transport regulation

In glucose-fed hamster fibroblast cultures maintained in a serum- and glutamine-free medium, DNP (2,4dinitrophenol) has no effect on the total cellular pool of ATP. Under these circumstances a marked effect of DNP on the hexose transport system can be demonstrated.

Abbreviations: DME = Dulbecco's modified Eagle's medium; DMSO = dimethylsulfoxide; DNP = 2,4-dinitrophenol. 


\section{INTRODUCTION}

In certain lines of hamster fibroblasts, glucose starvation brings about a marked enhancement of hexose uptake as compared with the rates observed in glucose-fed cultures $(2,3,5)$. Determination of the levels of the total cellular ATP pools showed that glucose-starvation of the cultures elicited a moderate but significant lowering of the ATP pool (10).

The effects of 2,4-dinitrophenol (DNP) on the two parameters also merit attention. It has been found that DNP or oligomycin brings about a marked enhancement of hexose uptake in NIL fibroblast cultures, maintained in standard DME medium (i.e. with 22 mM-glucose) $(4,7)$. As will appear in the present paper, DNP did in addition gradually bring about a lowering of the total ATP pool.

Perhaps a more noteworthy response was found in NIL cultures maintained in curtailed media, i.e. media devoid of serum as well as Lglutamine. It had already been observed that cultures maintained in curtailed media with the standard concentration of glucose lose most of the capacity of the hexose transport system (6). Even more surprising, prolonged presence of both DNP and glucose, preserve the hexose uptake at high levels (6). In the present paper we show that DNP added to curtailed medium in the presence of glucose permits the cultures to preserve the high levels of the cellular ATP pool as well.

\section{MATERIALS AND METHODS}

\subsection{Materials}

Hamster fibroblasts of the NIL line were cultured to near-confluence in Dulbecco's modified Eagle's medium (DME) (MA Bioproducts * 12-614) containing 22 mm-glucose and supplemented with $10 \%$ fetal calf serum. Cells were grown in $35 \mathrm{~mm}$ dishes (Falcon) in a humidified $10 \% \mathrm{CO}_{2}$ incubator. Twenty hours before uptake assays, the cultures were rinsed with modified DME medium (glucose and L-glutamine being absent). In some cases the cultures were pre-conditioned in serum-free medium devoid of L-glutamine as well as of pyruvate, glycine, serine and ferric nitrate. As indicated in individual experiments, glucose was omitted from the precondi- tioning media, or glucose was replaced with fructose.

2,4-dinitrophenol (DNP) was dissolved in dimethylsulfoxide (DMSO) and was added to cultures at a final concentration of $0.2 \mathrm{~mm}$ (final concentration of DMSO in the media, including the control cultures without DNP, was $0.1 \%$ ).

\subsection{Methods}

The uptake of hexose was determined as previously described $(2,4)$. In the procedure in the present series of experiments, ${ }^{14} \mathrm{C}$ galactose served as a ligand and $\mathrm{L}^{3}{ }^{3} \mathrm{H}$ glucose served in monitoring the effenciency of washing the cultures after the 10 minutes uptake test.

Determination of total cellular ADP and ATP pools were performed on parallel cultures. Following incubations, the medium was rapidly removed and the cells fixed by addition of $1 \mathrm{ml}$ of ice-cold $15 \%$ trichloroacetic acid containing 3.4 nmoles of xanthosine diphosphate (XDP) as external marker (1). Acid-soluble nucleotide pools were analyzed by high pressure liquid chromatography (HPLC) on a Whatman Partisil-10 SAX column with a Waters Associates ALC 204 instrument equipped with a programmer and a second pump for gradient elution. Gradient elution was performed as previously described $(9$, 10) and peaks were identified by $254 \mathrm{~nm}$ absorbance and integrated with a Hewlett-Packard HP3380A integrator. By this method amounts of nucleotides down to 50 picomoles could be measured with an error lower than $10 \%(10)$.

The insoluble material, remaining on the culture dishes after the extraction of the nucleotides was assayed for protein according to the method of LowRY et al. (8) when the cell had been maintained in serum-free media.

\section{RESULTS \\ 3.1.Effects of DNP in serum-glutamine-rich medium}

The data shown in Table I demonstrate that the hamster fibroblasts used in the present study react to changes in the growth medium in the same way as described in several earlier studies, (e.g. 2, 3, 10). Compared with the status of the cells maintained in DME without glucose, addition of glucose to the medium results in a down- 
Table I.

\begin{tabular}{|c|c|c|}
\hline $\begin{array}{l}\text { Conditioning } \\
\text { medium }\end{array}$ & $\begin{array}{l}\text { Galactose uptake } \\
\text { nmols } \cdot \mathrm{mg}^{-1} \\
\text { protein per } 10 \mathrm{~min}\end{array}$ & $\begin{array}{c}\text { Total cellular ATP } \\
\text { nmols } \cdot \mathrm{mg}^{-1} \\
\text { protein }\end{array}$ \\
\hline No glucose & 3.2 & 16 \\
\hline Glucose & 0.9 & 25 \\
\hline $\begin{array}{l}\text { Glucose + } \\
\text { DNP }\end{array}$ & 1.7 & 18 \\
\hline $\begin{array}{l}\text { Glucose + so- } \\
\text { dium floride }\end{array}$ & 1.9 & 13 \\
\hline Fructose & 2.7 & 27 \\
\hline
\end{tabular}

Near confluent NIL cultures were washed with DME containing $22 \mathrm{~mm}$-glucose or $22 \mathrm{~mm}$-fructose and were refed with DME containing $4 \mathrm{~mm}$ of L-glutamine, $10 \%$ calf serum and $22 \mathrm{~mm}$-glucose or fructose. The cultures were maintained for 20 hours at $37^{\circ} \mathrm{C}$ in the presence of $0.2 \mathrm{~mm}$-DNP or $0.5 \mathrm{~mm}$-sodium fluoride as indicated. All cultures contained 0.1\% DMSO. Galactose uptake and total cellular ATP pools were determined as described in the text. Determinations represent the average of two experiments.

regulation of the hexose uptake to about $30 \%$ and an increase in the ATP level to about $150 \%$. Furthermore, the data in Table I show that addition of DNP to the glucose containing cultures elicits a partial reversal of both of the glucose effects. Moreover, addition of fluoride (see legend to Table I) to the glucose-fed cultures also brings about a partial reversal of the glucose-mediated down-regulation. Fructose has scarcely any regulatory effect on the cellular ATP pools (10).

\subsection{Effect of DNP in curtailed medium}

Hamster fibroblasts maintained in a curtailed medium that is devoid of serum as well as glutamine, responded as summarized in Table II: (i) The down-regulation of hexose uptake mediated by glucose was more intense than that shown in Table I, i.e. down to only $10 \%$ of the value for cells in medium with no sugar present. (ii) The presence of DNP almost completely reversed this glucose-mediated down-regulation of hexose uptake. (iii) In contrast, the ATP pool and the ATP/ ADP ratio, remained high under all experimental conditions in which cells were maintained in the curtailed medium.

In the cells that had been maintained in the curtailed, serum- and glutamine-free medium for 20 hours, the rate of protein synthesis was decreased to $40-50 \%$ as compared to cells grown in DME serum-supplemented medium when assessed by the rate of incorporation of ${ }^{14} \mathrm{C}$ L-leucine (D.B. UllRey and C.W. Christopher, 1982, unpublished).

\section{DISCUSSION}

The data presented in this work confirm earlier findings that demonstrated a reversal by DNP of the glucose uptake mediated down-regulation of hexose both in a serum-glutamine rich medium and in a curtailed medium $(2,4,6)$.

Moreover, the data of the present paper extend earlier results to include measurements of the ATP levels. They show that DNP has no effect on the total cellular pool of ATP under circumstances where a marked reversal by DNP on the down-regulation of the hexose transport system can be demonstrated, i.e. in glucose-fed hamster

Table II.

Galactose uptake and total cellular ATP pools in NIL cells maintained in medium deprived of L-glutamine and serum

\begin{tabular}{lccc}
\hline \multicolumn{1}{c}{$\begin{array}{c}\text { Conditioning } \\
\text { medium }\end{array}$} & $\begin{array}{c}\text { Galactose uptake } \\
\text { nmols } \cdot \mathrm{mg}^{-1} \text { protein } \\
\text { per } 10 \mathrm{~min}\end{array}$ & $\begin{array}{c}\text { Total cellular ATP } \\
\text { nmols } \cdot \mathrm{mg}^{-1} \text { protein }\end{array}$ & ATP/ADP \\
\hline No hexose & 2.3 & 32 & 6.4 \\
Glucose & 0.3 & 33 & 5.3 \\
Glucose + DNP & 1.7 & 34 & 5.9 \\
\hline
\end{tabular}

Experimental conditions were described in the text and in the legend to Table I. Determinations represent the average of two experiments. 
fibroblast cultures maintained in a curtailed medium (6). The distribution of ATP between various pools may still need examination.

The results illustrated in Table II direct the attention to the problem of starvation of the cells for precursors of protein synthesis by withdrawal of serum and glutamine. In this connection, it might be recalled, that a decrease in protein synthesis, brought about by a general starvation of the eukaryote Tetrahymena pyriformis, did not result in any decrease of the ATP pool (9). In Tetrahymena a preferential synthesis of a number of proteins was observed during the starvation period, during which no decrease in the ATP pool was observable (9).

\section{ACKNOWLEDGEMENTS}

We are indebted to Professor MARTin OTtEsen, the Department of Chemistry of the Carlsberg Laboratory for discussions and helpful suggestions. This work has been supported by National Institutes of Health, Grant CA-28803 (E.R.), by the Danish Medical Research Council (P.P.) and by the National Science Foundation, Grant PCM 8021552 (H.M.K.).

\section{REFERENCES}

1. Chen, S.C., P.R. Brown \& D.M. Rosie: Extraction procedures for use prior to HPLC nucleotide analysis using microparticle chemically bonded packings. J. Chromatog. Sci. 15, 218-221 (1977)

2. Christopher, C.W., W.W. Colby \& D.B. UlLREY: Derepression and carrier turnover; evidence for two distinct mechanisms of hexose transport regulation in animal cells. J. Cell. Physiol. 89, 683-692 (1976)

3. Kalckar, H.M. \& D. Ullrey: Two distinct types of enhancement of galactose uptake into hamster cells: Tumor-virus transformation and hexose starvation. Proc. Natl. Acad. Sci. USA 70, 2502-2504 (1973)

4. Kalckar, H.E., C.W. Christopher \& D. UllREY: Uncoupler of oxidative phosphorylation promotes derepression of the hexose transport system in cultures of hamster cells. Proc. Natl. Acad. Sci. USA 76, 6453-6455 (1979)

5. Kalckar, H.M., C.W. Christopher \& D. ULLREY: Long-term regulation of amino acid and hexose transport in cultured animal cells. In: Cell Membranes, C. Fenoglio \& D.W. King eds., Thieme-Stratton, New York, pp. 350-364 (1980)

6. Kalckar, H.M., D. Ullrey \& R.A. Laursen: Effects of combined glutamine and serum deprivation on glucose control of hexose transport in mammalian fibroblast cultures. Proc. Natl. Acad. Sci. USA 77, 5958-5961 (1980)

7. KALCKAR, H.M.: Regulation of hexose transport-carrier activity in cultured animal fibroblasts. Another confrontation with cellular recycling requiring oxidative energy generation? Transact N.Y. Acad. Sci., Ser. II, Vol. 41, in press (1983)

8. Lowry, O.H., N.J. Rosebrough, A.L. Farr \& R.J. Randall: Protein measurement with the Folin phenol reagent. J. Biol. Chem. 193, 265275 (1951)

9. Plesner, P. \& K. KRISTIANSEN: Relation of protein synthesis to the content of adenosine polyphosphates. In: Regulation of Macromolecular Synthesis by Low Molecular Weight Mediators (G. Koch \& D. Richter, eds.). Academic Press, N.Y., 233-248 (1979)

10. Rapaport, E., C.W. Christopher, S.K. Svihovec, D. UllRey \& H.M. Kalckar: Selective high metabolic lability or uridine, guanosine and cytosine triphosphates in response to glucose deprivation and refeeding of untransformed and polyoma virus-transformed hamster fibroblasts. J. Cell. Physiol. $101,229-236$ (1979) 